\title{
Conceptualization and pilot application of a model-based environmental flow assessment adapted for intermittent rivers
}

\author{
Christos Theodoropoulos ${ }^{1}$ (D) . Christina Papadaki ${ }^{1}$. Leonidas Vardakas ${ }^{1}$ - Elias Dimitriou ${ }^{1}$ - Eleni Kalogianni ${ }^{1}$. \\ Nikolaos Skoulikidis ${ }^{1}$
}

Received: 8 June 2018 / Accepted: 30 November 2018 / Published online: 14 December 2018

(c) The Author(s) 2018

\begin{abstract}
Environmental flow assessments (EFAs) are widely researched and applied worldwide. However, model-based frameworks integrating the flow requirements of multiple ecosystem components have been primarily developed for perennial watercourses, being inherently inapplicable in intermittent rivers (IR), which are common worldwide and may dominate arid, semi-arid and mediterranean-climate regions. In this study, we conceptualized and pilot-applied a model-based EFA in a naturally intermittent Mediterranean river reach (Evrotas, southern Greece), guided by two fundamental principles: (1) environmental flows in IR should be delivered during specific aquatic states (AS) and (2) baseflows should be provided during prolonged dry periods to prevent artificial deviation from the natural AS-sequence. The habitat preferences of benthic macroinvertebrates and of three endemic fish species were evaluated, and a two-dimensional hydrodynamic-habitat model was applied to simulate habitat suitability at various discharges. We modelled the baseflow required to maintain disconnected water pools during dry periods and the optimal baseflow required to ensure the presence of suitable habitats after flow resumption. The results show that baseflows at the 25 th percentile of the abundant-riffles state can provide adequate habitat for the IR-specific communities. During prolonged dry periods, surface-groundwater interactions should be also considered for robust predictions. We highlight the use of hydrodynamic-habitat models in IR-based EFAs as a key-tool to estimate the AS timing and duration and, consequently, the timing-duration of the respective environmental flow components. Future studies should, inter alia, (1) include the aquatic-riparian vegetation to provide information on high flows-floods, and (2) incorporate groundwater models to account for surface-groundwater interactions towards a widely accepted IR-specific EFA framework.
\end{abstract}

Keywords IRES $\cdot$ Hydrodynamic habitat models $\cdot$ Ecological flows $\cdot$ Temporary streams $\cdot$ Temporary rivers

\section{Introduction}

Environmental flow assessments (EFAs) are implemented worldwide to evaluate the quantity, timing and quality of the water flows required to sustain freshwater ecosystems and the services they provide (Brisbane Declaration 2007). Among the numerous EFA methods available (Tharme 2003), hydrodynamic habitat models (HHMs) have long been considered powerful tools for accurate environmental flow implementations (Ahmadi-Nedushan et al. 2006; Lamouroux et al. 2010; WFD CIS 2015). HHMs typically

Christos Theodoropoulos

ctheodor@hcmr.gr

1 Hellenic Centre for Marine Research, Institute of Marine Biological Resources and Inland Waters, $46.7 \mathrm{~km}$ Athens-Sounio Ave, 19013 Anavyssos, Greece integrate two modules, (1) a hydrodynamic module, which evaluates the change in physical habitat as a function of flow by predicting water depths (D) and depth-averaged flow velocities (V) at multiple discharges, and (2) a habitat module, which compares the simulated values of $\mathrm{V}$ and $\mathrm{D}$ with the habitat preferences of aquatic biota to estimate habitat suitability at each simulated discharge (Acreman and Dunbar 2004; Gopal 2013). The output of HHMs (habitat suitability maps for each simulated discharge) provides water managers with a comprehensive visual representation for the development of environmental flow scenarios in hydrologically altered river reaches.

HHMs, and EFAs in general, have been primarily focused, evolved and applied in perennial watercourses (Waddle and Holmquist 2011; Leitner et al. 2017; Papadaki et al. 2017), neglecting intermittent rivers (IR), a large part of the earth's freshwater resources. These watercourses which naturally, 
periodically cease to flow (Datry et al. 2014) and may dry completely, account for more than $30 \%$ of the total length of the world's river network (Schneider et al. 2017) and dominate arid, semi-arid and mediterranean-climate regions (Schneider et al. 2017; Stubbington et al. 2018a). In contrast to their perennial counterparts, IR predictably experience a sequence of flow-defined aquatic states (AS) throughout the year (Gallart et al. 2012; Prat et al. 2014): (1) flood (overbank) flows-with unusually high flow; (2) abundant riffles-in which the riverbed is fully covered with water (pools and riffles are fully connected); (3) connected poolsa pool-dominated state, in which pools are connected with flowing water; (4) disconnected pools-when pools are present but isolated; (5) subsurface flow (interflow)—in which the riverbed is dry but the hyporheic zone remains saturated (6) dry, with no flow either at the surface or in the hyporheic zone. As IR shift between these wet and dry phases, they form a mosaic of aquatic and terrestrial habitats. The aquatic communities of IR have adapted to this extreme but predictable hydrological variability by developing specific physiological, behavioral, morphological and life-history strategies (Lytle and Poff 2004; Datry et al. 2014). Thus IR host very diverse - and often unique-aquatic, semi-aquatic and terrestrial communities, providing valuable ecosystem services, which have been previously acknowledged and documented (Stubbington et al. 2018b). Although IR-focused research is highly active, there are still notable knowledge gaps that need to be addressed (Datry et al. 2017; Stubbington et al. 2018b); delivering IR-specific environmental flows is currently a major relevant challenge (Costigan et al. 2017).

Riverbed drying and the persistence of pools in a dry reach affect the persistence of biota, including fish (Whiterod et al. 2017). Thus, the primary aim of the few available IR-based EFAs has been to maintain the minimum water discharge required to ensure the persistence of pools during periods of riverbed drying (Bernardo and Alves 1999) (hereafter referred to as dry periods), also emphasizing stakeholder participation (Conallin et al. 2018). Still, a naturally-occurring 'predictable' dry period may favor the establishment of IR-specific in-stream communities but prolonged human-induced dry periods, or by contrast, prolonged periods of flowing water (hereafter referred to as periods of flow permanence-Datry et al. 2007, 2017) may substantially degrade their structure beyond recovery (Chakona et al. 2008; Bêche et al. 2009; Bogan et al. 2015). These findings imply the importance of delivering environmental flows in IR during specific aquatic states to assist their flow-sensitive aquatic communities withstand the near-dry and dry conditions (resistance) and successfully recolonize upon flow resumption (resilience) (Bogan et al. 2017). Worldwide, however, EFAs in IR remain in their infancy (Datry et al. 2017), with model-based frameworks being currently absent.
In this study, we conceptualized and piloted a modelbased, IR-specific EFA in an intermittent river reach (Evrotas, southern Greece), guided by the following principles:

1. Environmental flows in IR should be specifically delivered during the abundant-riffles state; their timing and duration should be estimated and maintained based on historical hydrological information.

2. In prolonged dry periods only, extending beyond the predictable duration (before or after the normal dry period) baseflows should be delivered to maintain a disconnected-pools state for as long as this state would occur within the normal-predictable drying-rewetting sequence. This will ensure the 'predictable' presence of disconnected pools of water, which serve as refugia for fish and macroinvertebrate communities until flow resumption (McDonough et al. 2011; Datry et al. 2017).

Within our application, we (1) simulated the habitat preferences of benthic macroinvertebrates (BMs) and of three Evrotas-endemic cyprinid fish species in multiple discharges, (2) used hydrodynamic models to predict the baseflow required to maintain disconnected pools of water during dry periods, and (3) modelled the optimal baseflow required to ensure habitat suitability for the BM and fish communities during the abundant-riffles state. A fully functional aquatic community during the abundant-riffles state will have increased resistance during the near-dry (disconnected pools) state and an increased potential for successful recolonization and recovery after flow resumption (resilience), as implied-suggested by the findings of Fritz and Dodds (2004) and Bonada et al. (2007). We additionally highlight the use of HHMs as a key tool to predict the timing and duration of the various aquatic states and, consequently, the timing and duration of the respective environmental flow components, the most crucial step in delivering environmental flows in IR. We further explore shifts in fish habitat preferences from perennial to intermittent reaches, and identify future challenges and research priorities towards a widely accepted, common EFA framework adapted for intermittent rivers.

\section{Materials and methods}

\section{Overview of the methodology}

Our IR-specific EFA followed the steps outlined in Fig. 1 and summarized below:

(i) Estimation of the baseflow required to ensure adequate habitat suitability for multiple aquatic ecosystem components during the abundant-riffles state. This step is comparable to EFAs in perennial rivers, 


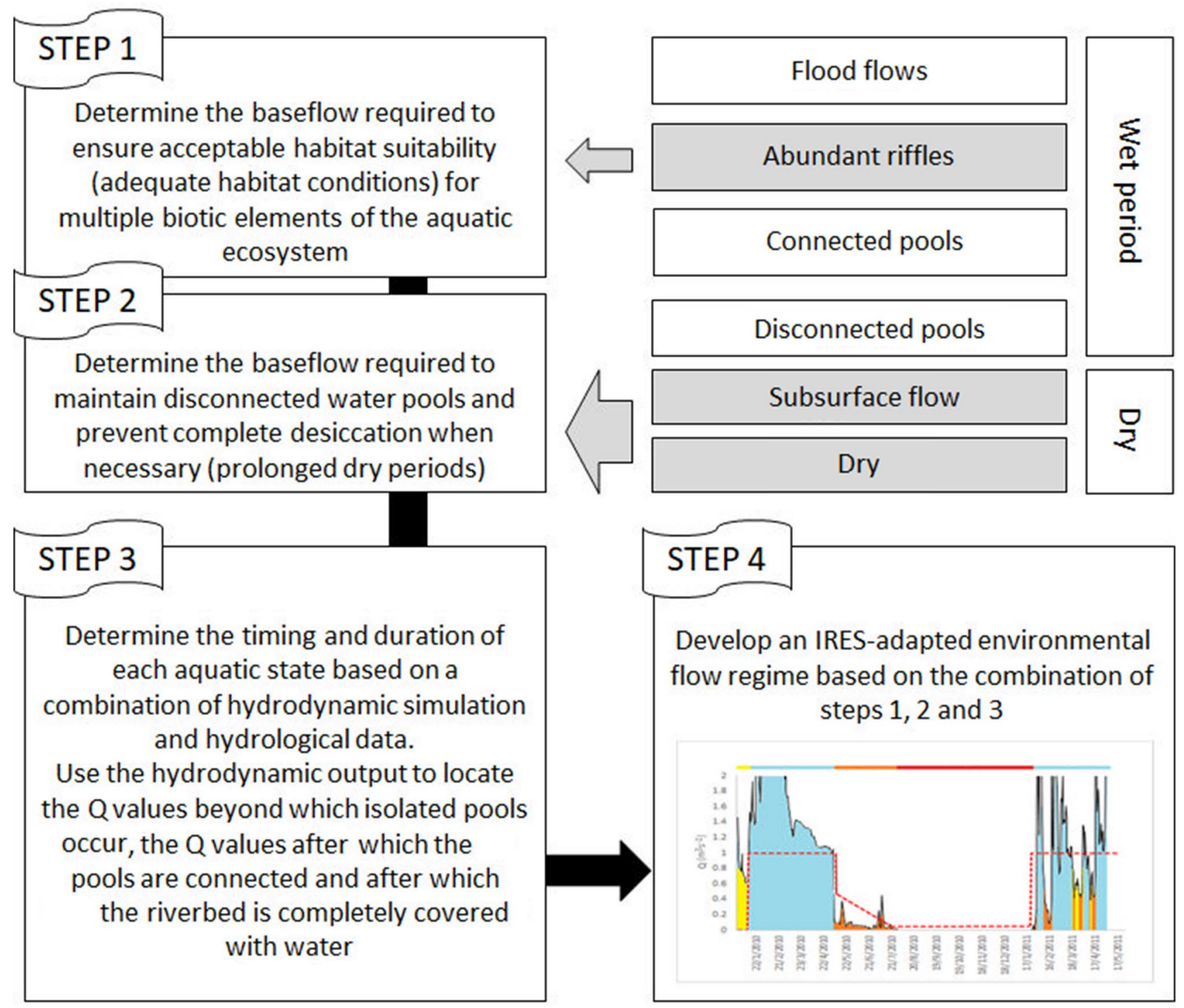

Fig. 1 The IR-specific environmental flow assessment framework conceptualized and applied in the study. The aquatic states in which environmental flows should be delivered are grey-shaded. $Q$ discharge

and aims to satisfy the habitat requirements of the aquatic communities, ensuring their ecological integrity.

(ii) Estimation of the baseflow required to maintain disconnected pools of water during dry periods.

(iii) Estimation of the timing and duration of each aquatic state. This step requires either continuous on-site measurements to visually estimate the timing using expert judgment, or the application of a hydrodynamic model in combination with historical hydrological information (see the pilot study for details). (iv) Development of an IR-adapted annual environmental flow regime based on the integration of the aforementioned steps.

\section{Pilot study}

Our study area was located in southern Greece, in a 20-km intermittent reach in the upper half of the Evrotas River (southeastern Peloponnese; Fig. 2). We selected this reach because: (1) it has been studied previously during another IR-targeting project (MIRAGE; Prat et al. 2014), its hydrological, topographical and ecological properties have been well-investigated (Cazemier et al. 2011; Skoulikidis et al. 


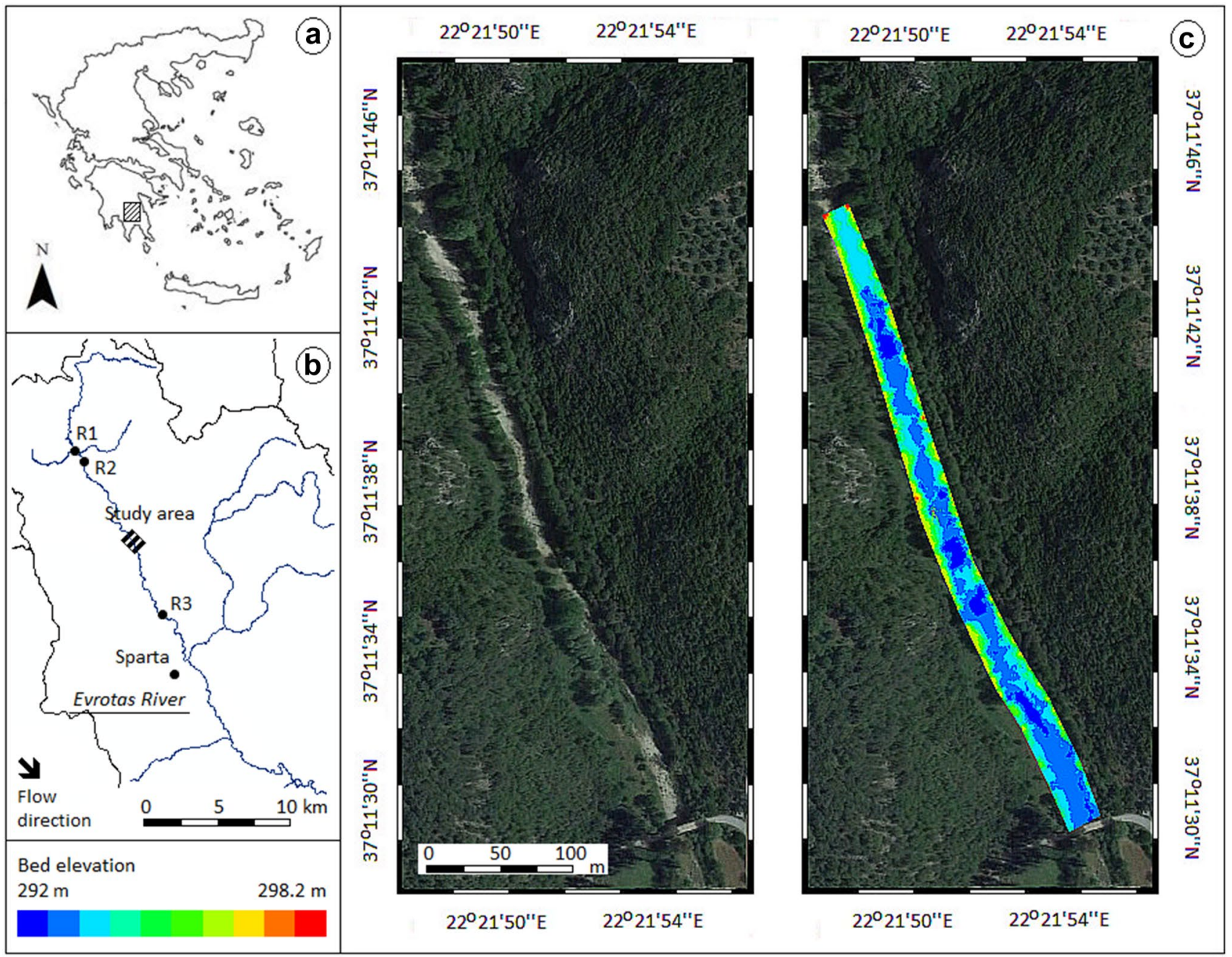

Fig. 2 a Location of the study area (Evrotas River, southern Greece). b The study reach in the upper half of the Evrotas River. c The riverbed elevation, based on the Real-Time-Kinematic-GPS acquired topography. $R 1$ and $R 3$ Perennial reference sites used for investigat-

2017a; Vardakas et al. 2017a) and (2) the area has a naturally intermittent flow regime, in which the dry period has been artificially prolonged during the past half century due to increasing irrigation (Cazemier et al. 2011; Skoulikidis et al. 2011). Local pressures in the upper reaches are related to irrigation of agricultural land, which results in unpredictable (and unmonitored) deviations from the naturally-occurring AS sequence, with artificially lowered flows during winter (Dec-Jan-Feb) and spring (Mar-Apr-May), and artificially prolonged dry periods during summer (Jun-Jul-Aug) (Cazemier et al. 2011). The study reach is located at an elevation of $227 \mathrm{~m}$ a.s.1., $22 \mathrm{~km}$ downstream of the main springs of the Evrotas River. Land use in the upper reaches consists of native coniferous forests and shrubs (67\%), agricultural areas, mainly olive groves and berry plantations (32.6\%) and urban areas $(0.4 \%)$. The river bed consists primarily of ing fish habitat-preference shifts between intermittent and perennial reaches. $R 2$ Reference intermittent site used for the development of the fish habitat suitability curves

alluvial sediments (cobbles and pebbles). Sand and silt is mainly deposited in pool areas and the reach is characterized by dense submerged macrophyte beds, especially during summer, before the dry period.

The fish species inhabiting the study reach are of high conservation value, listed in the IUCN Red List of Threatened Species (IUCN 2017). The fish community includes (1) the endemic Evrotas chub Squalius keadicus (Stephanidis 1971), classified as 'endangered', (2) the Spartian minnowroach Tropidophoxinellus spartiaticus (Schmidt-Ries 1943), classified as 'vulnerable' and endemic to the southern Peloponnese peninsula and (3) the Evrotas minnow Pelasgus laconicus (Kottelat and Barbieri 2004), classified as 'critically endangered' and confined to the Evrotas and Alphios rivers (Vardakas et al. 2015). 


\section{Topographic data}

A 443 m-long reach (Fig. 2) was surveyed using a real-time kinematic (RTK) GPS consisting of the Spectra Precision SP60 GNSS Receiver and the MobileMapper 10 GIS-GPS Receiver (Trimble Inc., USA). Channel topography was mapped using 719 points recording longitude (X), latitude $(\mathrm{Y})$ and bottom elevation $(\mathrm{H})$. Slope breaks and similar areas with rapid relief changes were mapped with a higher density of points, and fewer points were allocated in flat surfaces. The topographic data (X, Y, H points) were then imported into the Blue Kenue software (CHC 2011) to linearly interpolate channel topography and generate a triangular computational grid representative of the study reach.

\section{Hydrodynamic simulation, calibration and validation}

Boundary and initial conditions were defined prior to running the 2D hydrodynamic simulation. Water discharge (Q) was prescribed at the upstream boundary and water surface elevation $(Z)$ at the downstream boundary based on a stagedischarge curve developed using hydrological information from a permanent gauging station. The TELEMAC-2D v6.2 hydrodynamic model (Galland et al. 1991) was used to simulate water depths (D) and depth-averaged flow velocities (V) in various $\mathrm{Q}$ scenarios. The TELEMAC-2D code applies the finite element method (Hervouet 2007) to solve the shallowwater St-Venant equations (conservation of mass, $\mathrm{x}$-wise momentum, y-wise momentum).

The hydrodynamic model was calibrated and validated for three different discharges $\left(0.008 \mathrm{~m}^{3} \mathrm{~s}^{-1}, 0.02 \mathrm{~m}^{3} \mathrm{~s}^{-1}\right.$ and $0.5 \mathrm{~m}^{3} \mathrm{~s}^{-1}$ ) using hydrological cross-sectional information (V and D) for the study reach. The $0.02-\mathrm{m}^{3} \mathrm{~s}^{-1} \mathrm{Q}$ was used for calibration and the remaining discharges were used to validate the model. Calibration-validation was applied by properly adjusting the Manning's roughness coefficient (n) at different sections of the study reach, based on a preliminary on-site visual assessment of the substrate types (S) according to the categories defined by Schneider et al. (2010), until an acceptable combination of $\mathrm{R}^{2}$ values between the predicted and observed $\mathrm{V}$ and $\mathrm{D}$ was achieved. The validated model was used to simulate 17 discharge scenarios ranging from 0.008 to $9 \mathrm{~m}^{3} \mathrm{~s}^{-1}$ for determining the environmental flow during the abundant-flows state, while additional simulations were applied in lower discharges, ranging from 0.0001 to $0.005 \mathrm{~m}^{3} \mathrm{~s}^{-1}$ to determine the baseflow required to maintain disconnected pools during the dry states.

\section{Habitat suitability modeling}

The habitat preferences of four biotic elements of the aquatic ecosystem were used to model and map habitat suitability (K) based on the results of the hydrodynamic simulation: benthic macroinvertebrates and the three endemic cyprinid fish species. For the Evrotas chub, two size classes were recorded; large, total length $(\mathrm{TL})<10 \mathrm{~cm}$, corresponding to juveniles and small, TL $>10 \mathrm{~cm}$, corresponding to adults. Size classes were not differentiated for the smallersized Spartian minnowroach and the Evrotas minnow due to the increased uncertainty in defining size-class-based generations.

\section{Fish}

To account for the artificially altered, intermittent flow regime of the study reach, fish data (the abundance of each species) and associated habitat information (V, D and $\mathrm{S})$ were recorded in multiple microhabitats (approx. $4 \mathrm{~m}^{2}$ each) from an unimpacted, naturally-intermittent site upstream of the study reach (R2, Fig. 2), to ensure sampling of wellestablished, fully-functional fish communities. Samples were collected in two campaigns, during abundant-flows states (early summer in 2014 and 2015, before dry-phase onset). Similarly to Vardakas et al. (2017b), we used an EFKO electrofishing DC unit (Honda $7 \mathrm{kVA}$ generator, $150 \mathrm{~m}$ cable, $1.5 \mathrm{~m}$ anode pole, 6 A DC output, voltage range $300-600 \mathrm{~V}$ ) following a modified point-abundance procedure (Copp 1989; Santos and Ferreira 2008). Sampling was applied in a downstream-upstream direction and in a meandering manner to sample all habitat types. In total, 101 microhabitat samples (relating V, D and S with fish abundance) were collected. Fish were identified to species level, counted, and their size class recorded at $5-\mathrm{cm}$ intervals, then returned alive to the river.

Fish habitat preferences were assessed by developing habitat suitability curves (HSCs) based on the approach of Bovee (1986). We related the variables of the hydrodynamic output ( $\mathrm{V}$ and $\mathrm{D}$ ) to the habitat suitability with an index which ranged from 0 (unsuitable) to 1 (highly suitable). Habitat suitability was directly related to fish abundance, implying that the most suitable habitats were the ones with higher abundance values. The influence of extreme values was downweighted by log-transforming the abundance of fish per microhabitat sample (Brosse and Lek 2000; Fukuda et al. 2011). The process was implemented in $\mathrm{R}$ version 3.1.1 (R Core Team 2014) using the smooth.spline function which fits smooth curves to the input data using 3rd-order polynomials. Each polynomial allows for a turn within the adjusted curve, to be coherent with the ecological gradient theory (Austin 2007). 
Following the same approach, HSCs were also developed for two reference perennial reaches (R1 and R3-Fig. 2), upstream and downstream of our intermittent study reach, using the microhabitat dataset of Vardakas et al. (2017b).

\section{Benthic macroinvertebrates}

The habitat preferences of benthic macroinvertebrates were evaluated using the dataset collected in Theodoropoulos et al. (2018a), which consists of 380 microhabitat observations that relate $\mathrm{V}, \mathrm{D}$ and $\mathrm{S}$ to a community-metrics-based calculation of habitat suitability (integrating number of families, number of Ephemeroptera, Plecoptera and Trichoptera families, Shannon-Wiener diversity and total abundance). The dataset covers a wide range of river types and, as indicated in Theodoropoulos et al. (2018b), the use of a metricsbased habitat suitability approach enables accurate replication of the process in river reaches with similar hydrological and hydraulic properties, as the specific reach, despite the possible spatial and temporal variation of the macroinvertebrate distribution.

A fuzzy-rule-based Bayesian algorithm (FRB), implemented in the HABFUZZ software (Theodoropoulos et al. 2016), was trained and cross-validated using the data set. In the FRB:

(i) The numerical values of $\mathrm{V}$ and $\mathrm{D}$ are converted to overlapping, five-class, trapezoidal-shaped fuzzy sets. The $\mathrm{K}$ values are classified (non-overlapping) into five classes $[(0,0.2)$, bad; $(0.2,0.4)$, poor; $(0.4,0.6)$, moderate; $(0.6,0.8)$, good; $(0.8,1)$, high; Table 1].

(ii) Each numerical value of $\mathrm{V}$ and $\mathrm{D}$ is assigned to one or more fuzzy sets with a membership degree between zero and one (Table 1); in our application, the type of substrate was treated as a crisp input and classified based on Schneider et al. (2010).

(iii) The training dataset (benthos-GR), with a priori calculated $\mathrm{K}$ values, is used to develop sets of datadriven IF-THEN rules, relating the input fuzzy sets with a specific $\mathrm{K}$ class. The fuzzy membership degree (MD) of each input variable (V, D and $\mathrm{S}$ ) is considered as the probability of occurrence of the particular fuzzy set, such as 'IF V is low with a membership degree of 1 AND D is moderate with a MD of 1 AND $S$ is gravel with a MD of 1 THEN $\mathrm{K}$ is high with a MD of 0.3 and good with a MD of 0.7 '.

(iv) The IF-THEN rules are then combined using the Bayesian joint probability, so that (referring to the previous example) the probability of the specific microhabitat's K being high is the joint probability that $\mathrm{V}$ is low AND D is moderate AND $\mathrm{S}$ is gravel AND K is high $(1 \times 1 \times 1 \times 0.3=0.3)$, while the probability of $\mathrm{K}$ being good is the joint probability that $\mathrm{V}$ is low AND D is moderate AND $\mathrm{S}$ is gravel AND $\mathrm{K}$ is $\operatorname{good}(1 \times 1 \times 1 \times 0.7=0.7)$. Based on a utility function (Brookes et al. 2010), a score is assigned to each K class (bad: 0.1; poor: 0.3; moderate: 0.5; good: 0.7; high: 0.9) and the habitat suitability of each microhabitat is predicted using the equation:

$$
\mathrm{K}=\sum \mathrm{M}_{\mathrm{ij}} \mathrm{S}_{\mathrm{ij}}
$$

where, $\mathrm{K}$ is the predicted habitat suitability. $\mathrm{M}_{\mathrm{ij}}$ denotes the joint probability of occurrence of each $\kappa$ class. $S_{i j}$ denotes the score of each $\kappa$
Table 1 Fuzzy sets of the hydraulic variables and the habitat suitability (adapted from Theodoropoulos et al. 2018a)

\begin{tabular}{llllll}
\hline Variable & Fuzzy set class & Fuzzy set parameters & Variable & Crisp set class & Crisp set parameters \\
\hline \multirow{4}{*}{ V $(\mathrm{m})$} & & $\mathrm{K}$ & Bad & $\{0,0.2\}$ \\
& Very low & $\{0,0,0.05,0.1\}$ & & Poor & $\{0.2,0.4\}$ \\
& Low & $\{0.05,0.1,0.15,0.2\}$ & Moderate & $\{0.4,0.6\}$ \\
& Moderate & $\{0.15,0.2,0.4,0.5\}$ & Good & $\{0.6,0.8\}$ \\
& High & $\{0.4,0.5,0.7,0.8\}$ & & High & $\{0.8,1\}$ \\
& Very high & $\{0.7,0.8,0.8,0.8\}$ & & & \\
& & & Boulders & 0.070 \\
$\mathrm{D}(\mathrm{m})$ & Very shallow & $\{0,0,0.1,0.15\}$ & & Large stones & 0.050 \\
& Shallow & $\{0.15,0.2,0.3,0.35\}$ & & Small stones & 0.040 \\
& Moderate & $\{0.3,0.35,0.55,0.6\}$ & & Large gravel & 0.030 \\
& Deep & $\{0.55,0.6,0.7,0.75\}$ & & Medium gravel & 0.026 \\
& Very deep & $\{0.75,0.8,0.8,0.8\}$ & Fine gravel & 0.024 \\
& & & Sand & 0.022 \\
& & & Silt & 0.020 \\
\hline
\end{tabular}

V, flow velocity; D, water depth; $\mathrm{S}$, substrate; $\mathrm{K}$, habitat suitability 
class. For the previous example, $\mathrm{K}$ equals to $0.7 \times 0.9+0.3 \times 0.7=0.84$ (high) .

\section{Environmental flow selection}

The output of the hydrodynamic model (D and V values) at each simulated discharge, in combination with the visually recorded substrate types, was used as input to the habitat models of fish and BM, which calculated $\mathrm{K}$ at each node of the computational grid, based on the above algorithms. The habitat suitability of each biotic element at each simulated $\mathrm{Q}$ was then visualized using the BlueKenue software ( $\mathrm{CHC}$ 2011).

At each Q scenario, the Weighted Usable Area (WUA), the area $\left(\mathrm{m}^{2}\right)$ of the study reach that is being used by the aquatic communities at each discharge, was calculated by multiplying the $\mathrm{K}$ value of each cell of the computational grid with its relevant cell area, aggregating all values and depicting them in a discharge-WUA plot. Optimization matrices were developed for 17 discharge scenarios for each biotic element, according to the optimization criterion of Bovee (1982), in which the discharge values are arrayed across the top of the matrix and the WUA values for the biotic elements are recorded accordingly. The minimum WUA value is identified for each discharge and the environmental flow is estimated based on the discharge with the highest WUA value among all biotic elements (Bovee et al. 1998). Moreover, we normalized the WUA values in a $0-1$ scale (nWUA) and applied a 5-class system, similarly to Gillenwater et al. (2006) and based on the status classification of the Water Framework Directive 2000/60/EC (WFD; European Union Council 2000) (bad: $0<\mathrm{nWUA} \leq 0.2$, poor: $0.2<$ nWUA $\leq 0.4$, moderate: $0.4<$ nWUA $\leq 0.6$, good: $0.6<$ nWUA $\leq 0.8$, high: $0.8<$ nWUA $\leq 1)$; all discharges with a WUA higher than 0.6 (falling into the good and high WFD classes, indicating no or slight deviation from natural conditions) were considered acceptable.

\section{Environmental flow regime}

Based on the results of the hydrodynamic simulation, we estimated the $Q$ values at which a shift between aquatic states (AS) is observed. In combination with daily discharge data for the study reach for the years 2010 and 2011, we estimated the timing and duration of each AS and developed an annually repeating AS pattern. This pattern was used to propose the final annually repeating environmental flow regime for the study reach.

\section{Results}

\section{Computational grid properties}

A computational grid consisting of 25,998 triangular cells and 13,477 nodes with a $0.8 \mathrm{~m}$ spatial resolution was generated for the study reach. The $\mathrm{R}^{2}$ coefficient between the predicted and observed $\mathrm{D}$ and $\mathrm{V}$ values was $>0.8$ for both the calibration and validation data sets $(0.83-0.95)$; the correlations were significant $(\mathrm{p}<0.01)$, suggesting acceptable performance of the hydrodynamic model. Based on the recorded substrate types, the Manning's roughness coefficient in the validated model ranged from 0.028 to 0.045 . Depth values ranged from $0.1 \mathrm{~mm}$ to $54 \mathrm{~cm}$ for the lowest discharge simulated $\left(0.008 \mathrm{~m}^{3} \mathrm{~s}^{-1}\right)$ and from $1 \mathrm{~mm}$ to $5 \mathrm{~m}$ for the highest discharge $\left(9 \mathrm{~m}^{3} \mathrm{~s}^{-1}\right)$. V values ranged from 0.01 to $0.88 \mathrm{~m} \mathrm{~s}^{-1}$ for the lowest simulated $\mathrm{Q}\left(0.008 \mathrm{~m}^{3} \mathrm{~s}^{-1}\right)$ and from 0.01 to $2.69 \mathrm{~m} \mathrm{~s}^{-1}$ for the highest simulated $\mathrm{Q}$ $\left(9 \mathrm{~m}^{3} \mathrm{~s}^{-1}\right)$.

\section{Fish microhabitat preferences}

In the perennial reaches, habitat suitability $(\mathrm{K})$ values for flow velocity peaked for the minnow, minnowroach and small chub at $0.2-0.4 \mathrm{~m} \mathrm{~s}^{-1}$ and for the large chub at $0.6-0.8 \mathrm{~m} \mathrm{~s}^{-1}$ (Fig. 3a, upper panes); in the intermittent reach, $\mathrm{K}$ peaked at $0-0.1 \mathrm{~m} \mathrm{~s}^{-1}$ for the minnow and minnowroach, at $0.1-0.2 \mathrm{~m} \mathrm{~s}^{-1}$ for the large chub and at $0.5-0.6 \mathrm{~m} \mathrm{~s}^{-1}$ for the small chub (Fig. 3b, upper panes). For depth, $\mathrm{K}$ values for the minnow and the large chub peaked at $1-1.2 \mathrm{~m}$ in both the perennial and intermittent reaches. For the minnowroach, $\mathrm{K}$ peaked at $0.6-0.8 \mathrm{~m}$ in the perennial reaches and at $1-1.2 \mathrm{~m}$ in the intermittent reach. For the small chub, $\mathrm{K}$ peaked at $0.4-0.6$ in the perennial reaches (Fig. 3a, lower panes) and at $0.0-0.2 \mathrm{~m}$ in the intermittent reach (Fig. 3b, lower panes).

\section{Determination of environmental flows during the abundant-riffles state}

The habitat suitability values, mapped for the various discharges (representing candidate Q scenarios for the abundant-riffles state) at each node of the computational grid, are depicted in Fig. 4a (large chub), Fig. 4b (small chub), Fig. 5a (minnowroach), Fig. 5b (minnow) and Fig. 6 (benthic macroinvertebrates). In addition, the weighted usable area (WUA) of each biotic element, normalized in a $0-1$ scale, is illustrated in Fig. 7. The WUA of the large chub was acceptable at discharges $>1 \mathrm{~m}^{3} \mathrm{~s}^{-1}$ and peaked above $\mathrm{Q}=9 \mathrm{~m}^{3} \mathrm{~s}^{-1}$ (LC, Fig. 7). Large chub preferred high $\mathrm{V}$ and $\mathrm{D}$ values, which were mostly found at the highest discharges (Fig. 4a). 

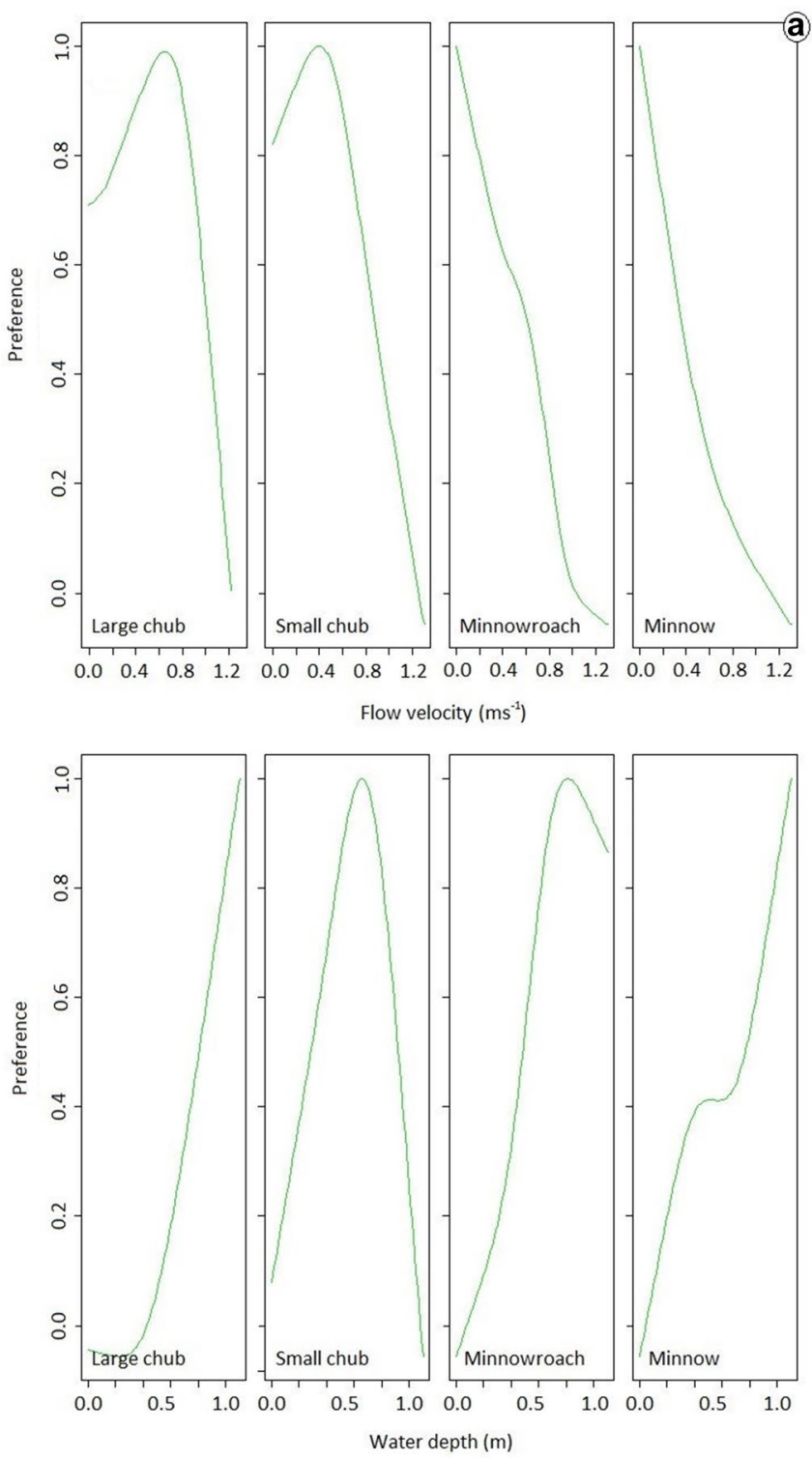

Fig. 3 Habitat suitability curves for the endemic Evrotas chub Squalius keadicus (two size classes: large, total length (TL) $<10 \mathrm{~cm}$, corresponding to juveniles; small, TL $>10 \mathrm{~cm}$, corresponding to adults),

The WUA of the small chub peaked at $\mathrm{Q}=1 \mathrm{~m}^{3} \mathrm{~s}^{-1}$, but was acceptable at the lowest discharges simulated and up to $\mathrm{Q}=3 \mathrm{~m}^{3} \mathrm{~s}^{-1}$ (SC, Fig. 7). Most microhabitats with good or high $\mathrm{K}$ were recorded between $\mathrm{Q}=0.8 \mathrm{~m}^{3} \mathrm{~s}^{-1}$ and $\mathrm{Q}=2 \mathrm{~m}^{3} \mathrm{~s}^{-1}$. Acceptable WUA for the Spartian minnowroach was recorded for $\mathrm{Q}$ values $>1 \mathrm{~m}^{3} \mathrm{~s}^{-1}$, peaking at very high discharges $\left(9 \mathrm{~m}^{3} \mathrm{~s}^{-1}\right)$ and remaining high at even greater $Q$ values (MR, Fig. 7). In a similar pattern, the WUA of the Evrotas minnow was acceptable above $0.1 \mathrm{~m}^{3} \mathrm{~s}^{-1}$, peaking at the highest discharges $\left(5 \mathrm{~m}^{3} \mathrm{~s}^{-1}\right)$ and remaining stable at higher $Q$ values (M, Fig. 7). The Spartian minnowroach was found at discharges higher than $\mathrm{Q}=1 \mathrm{~m}^{3} \mathrm{~s}^{-1}$
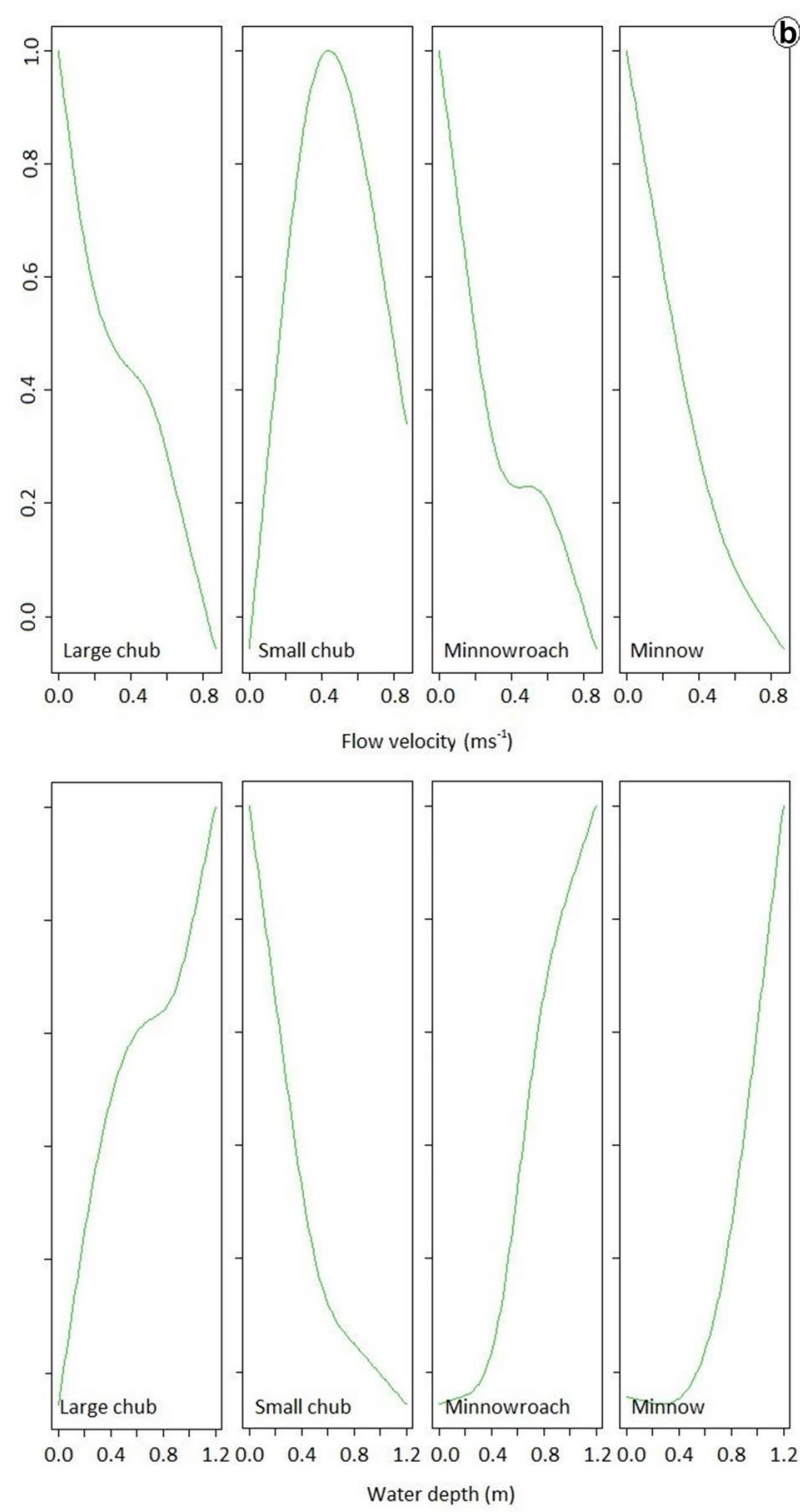

the Spartian minnowroach Tropidophoxinellus spartiaticus and the Evrotas minnow Pelasgus laconicus. a perennial reaches, b intermittent reaches

(Fig. 5a) while most microhabitats with good/high $\mathrm{K}$ for the Evrotas minnow were recorded between $\mathrm{Q}=0.1 \mathrm{~m}^{3} \mathrm{~s}^{-1}$ and $\mathrm{Q}=0.5 \mathrm{~m}^{3} \mathrm{~s}^{-1}$ (Fig. 5b). Acceptable habitat suitability for benthic macroinvertebrates was recorded at $\mathrm{Q}$ values between 0.8 and $4 \mathrm{~m}^{3} \mathrm{~s}^{-1}$ (Fig. 6), while discharges ranging from 0.8 to $7 \mathrm{~m}^{3} \mathrm{~s}^{-1}$ resulted in an acceptable WUA (BM, Fig. 7).

Based on both the WFD-oriented classification and the criterion of Bovee (data not shown), the minimum acceptable baseflow (environmental flow) during the abundantriffles state should be at least $1 \mathrm{~m}^{3} \mathrm{~s}^{-1}$. 


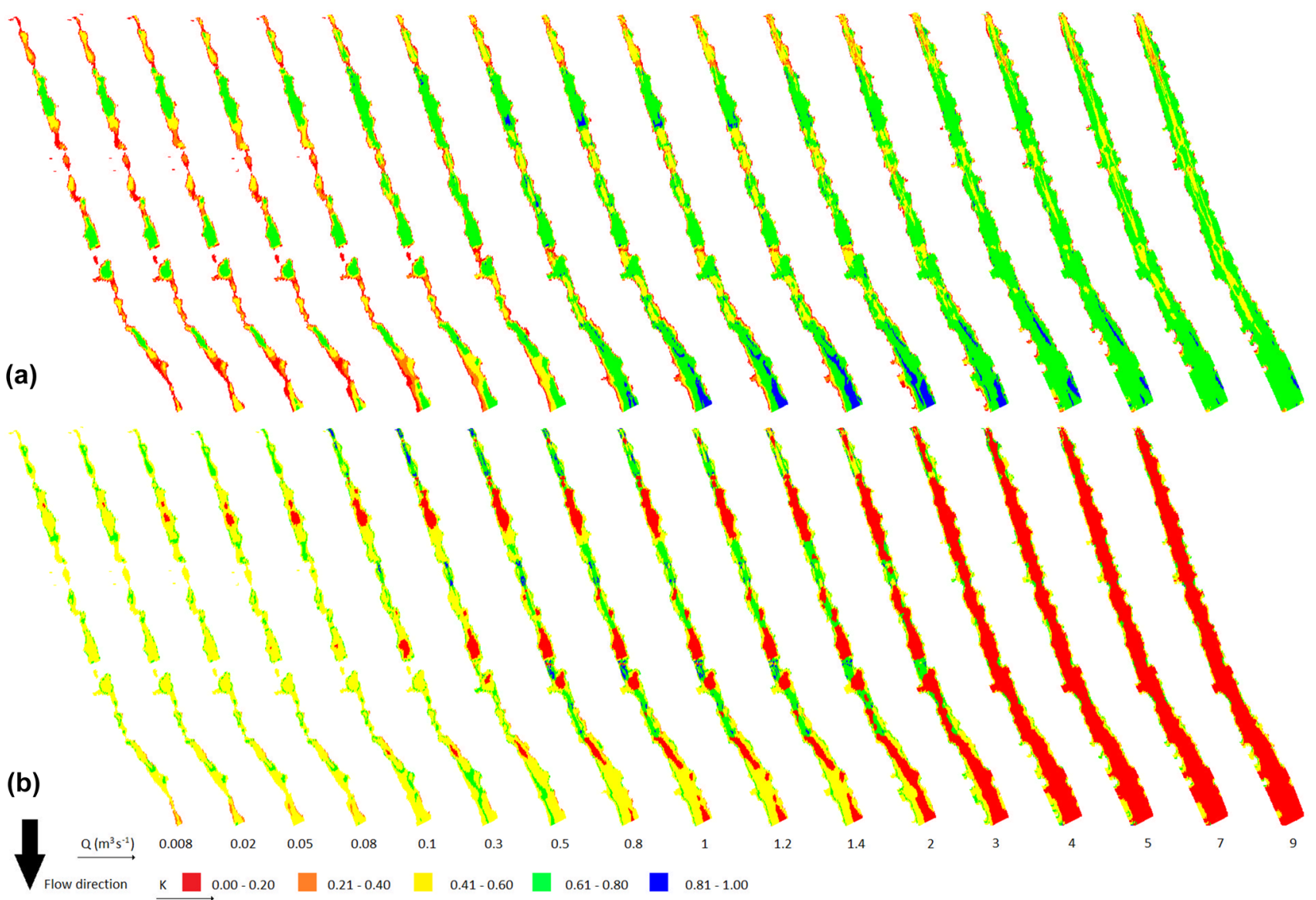

Fig. 4 Habitat suitability mapping for the Evrotas chub in the various simulated discharges [a total length $>10 \mathrm{~cm}$ (large); $\mathbf{b}$ total length $<10$ $\mathrm{cm}$ (small)]. Values $>0.6$ are considered acceptable. $Q$ discharge, $K$ habitat suitability

\section{Determination of the environmental flow during the dry period}

Based on the hydrodynamic simulation, very low flows were capable of maintaining disconnected pools of water during the dry period (Fig. 8). Discharges $<0.001 \mathrm{~m}^{3} \mathrm{~s}^{-1}$ (5th percentile of mean daily discharge; 2-year period excluding the dry states) resulted in scattered disconnected pools of $\leq 0.7$-m deep. Even at lower discharges (data not shown) water filled these pools, resulting in similar depths. In higher discharges $\left(0.008 \mathrm{~m}^{3} \mathrm{~s}^{-1}\right)$, the number of pools slightly increased but with no obvious differences; the existing pools in $\mathrm{Q}<0.008 \mathrm{~m}^{3} \mathrm{~s}^{-1}$ became deeper and wider, being connected with water in $\mathrm{Q}=0.5 \mathrm{~m}^{3} \mathrm{~s}^{-1}$.

\section{Determination of the timing and duration of aquatic states}

The magnitude of the environmental flow during the abundant-riffles state was calculated as $1 \mathrm{~m}^{3} \mathrm{~s}^{-1}$. The connectedpools state initiates at $\mathrm{Q}=0.5 \mathrm{~m}^{3} \mathrm{~s}^{-1}$, with the river flow becoming disconnected at lower discharges (disconnectedpools state; Fig. 8). The abundant-riffles state gradually occurs at $\mathrm{Q}>0.8-1 \mathrm{~m}^{3} \mathrm{~s}^{-1}$, when the riverbed is almost fully covered with flowing water. In combination with daily discharge data from the study reach, the AS sequence is the following: (1) abundant riffles: early January to early May (or late April); (2) transition between connected- and disconnected-pools states: middle May to late July; (3) disconnected-pools and dry states: late July to late November, extending up to early January in extreme conditions (Fig. 9).

\section{Development of an IR-adapted environmental flow regime}

Based on the integration of the hydrodynamic-habitat and hydrological data, the annually repeating environmental flow regime for the study reach is depicted in Fig. 9. A baseflow of $1 \mathrm{~m}^{3} \mathrm{~s}^{-1}$ (minimum acceptable) should be delivered from early January to early May (abundant-riffles state), gradually decreasing to $<0.5 \mathrm{~m}^{3} \mathrm{~s}^{-1}$ from mid-May to early July, 


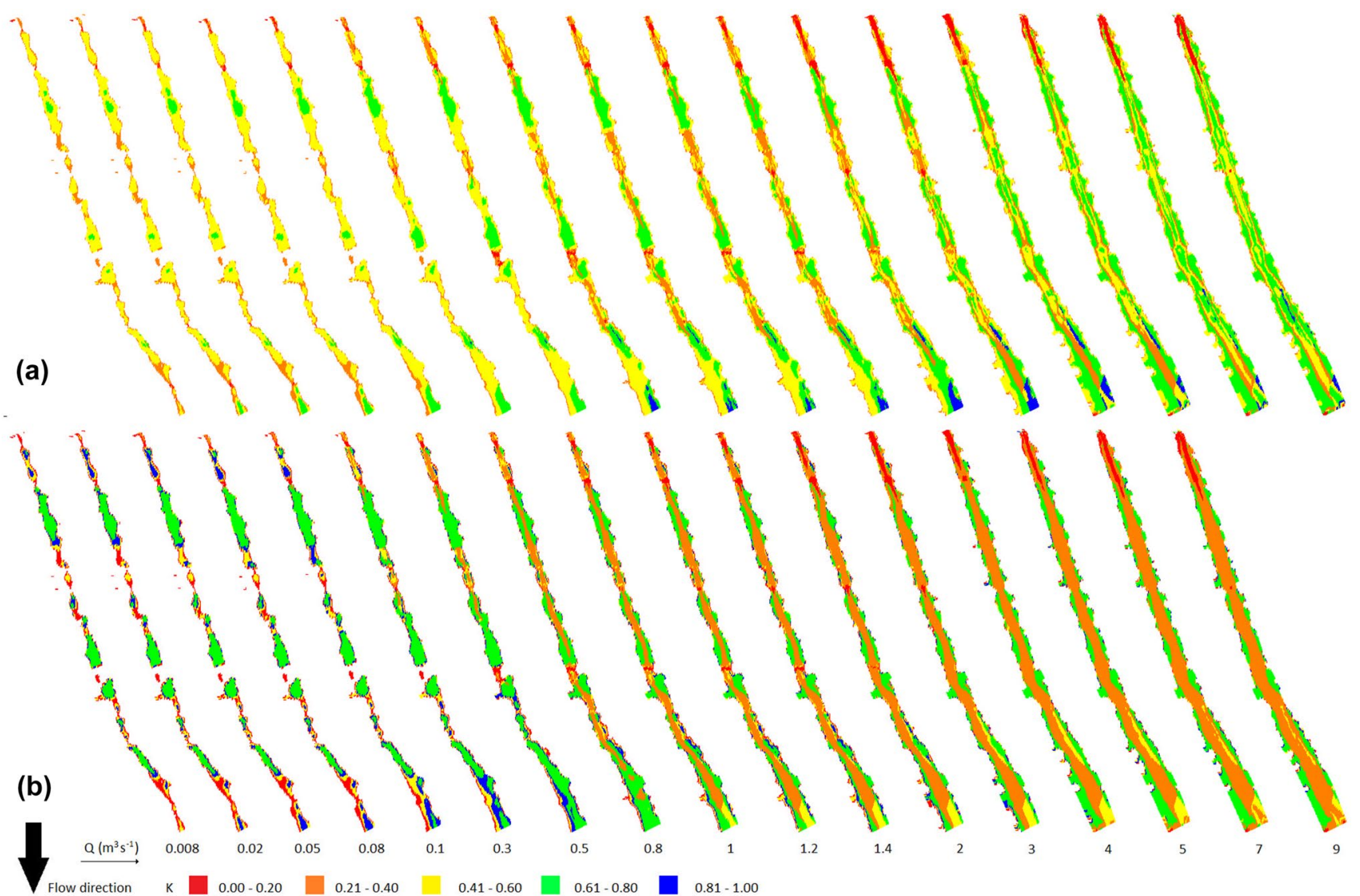

Fig. 5 Habitat suitability mapping for the Spartian minnowroach (a) and the Evrotas minnow (b) in the various simulated discharges. Values $>$ 0.6 are considered acceptable. $Q$ discharge, $K$ habitat suitability

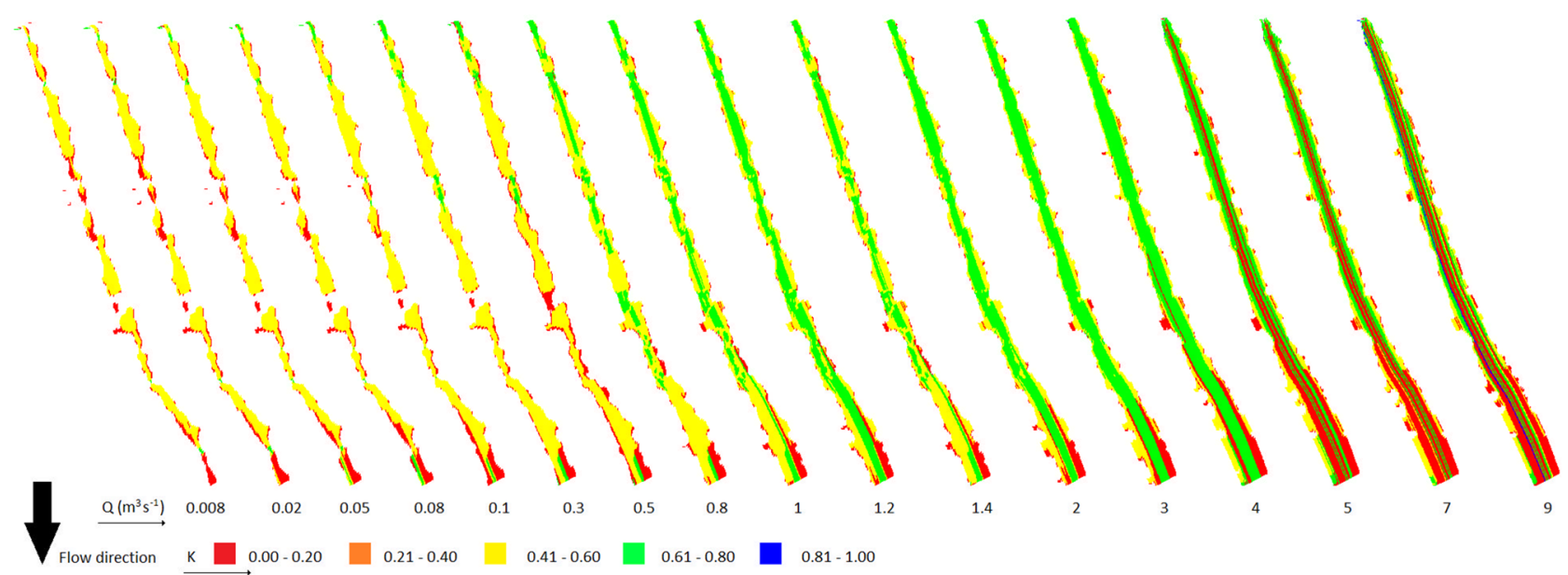

Fig. 6 Habitat suitability mapping for benthic macroinvertebrates in the various simulated discharges. Values $>0.6$ are considered acceptable. $Q$ discharge, $K$ habitat suitability

(to maintain a connected-pools state, gradually transitioning to disconnected-pools) and reaching very low values $\left(0.001 \mathrm{~m}^{3} \mathrm{~s}^{-1}\right.$ or even zero) from late July to late November/ early December (disconnected-pools, subsurface-flow and dry state). 


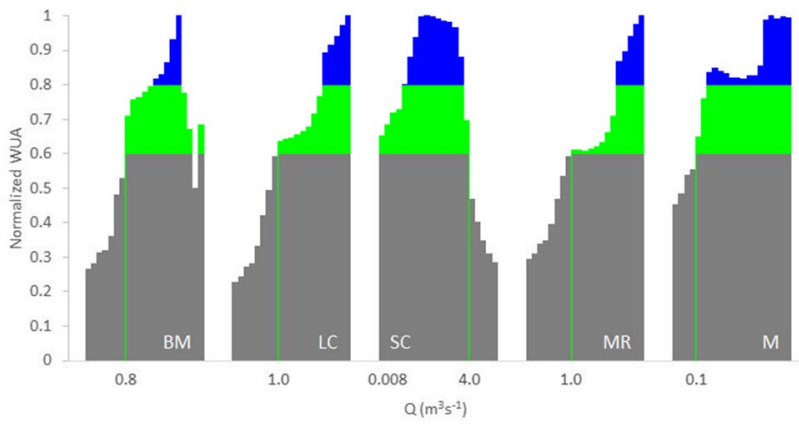

Fig. 7 Normalized Weighted Usable Area (WUA) per biotic element. $B M$ benthic macroinvertebrates, $L C$ large chub, $S C$ small chub, $M R$ minnowroach, $M$ minnow. Acceptable discharges (Q) based on the Water Framework Directive 2000/60/EC (good status: WUA > 0.6; high status: WUA $>0.8$ ) for each element have been accordingly shaded-colored

\section{Discussion}

\section{Methodological adaptations towards IR-specific EFAs}

Intermittent rivers, in contrast to their perennial counterparts, are characterized by considerable hydrological and geomorphological variability (Cid et al. 2017; Skoulikidis et al. 2017b), with intra- and inter-annually repeating transitions between aquatic and terrestrial conditions-habitats (Larned et al. 2010; Stubbington et al. 2017). The aquatic biota of natural IR have, in turn, been adapted to these complex hydrogeomorphological patterns (Datry et al. 2017). As a result, the principles, methods and tools, developed for

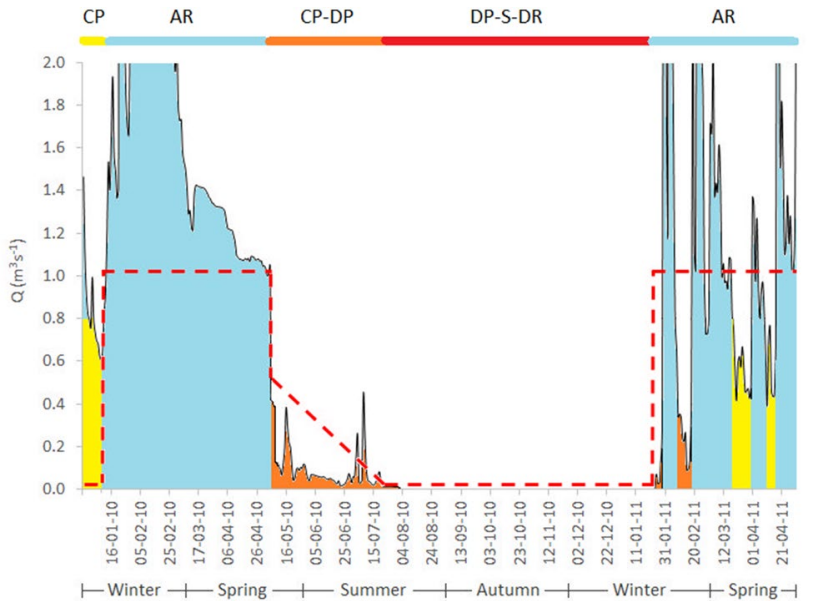

Fig. 9 Timing and duration of aquatic states in the study reach. $A R$ abundant riffles, $C P$ connected pools, $D P$ disconnected pools, $C P$ $D P$ transition between CP and DP, DP-S-DR transition between DP, and the dry states (subsurface-flow and dry). The flood-flows state is included in $A R$. Dotted lines highlight the annual environmental flow regime

and applied in perennial rivers need to be adapted, reformed and re-evaluated for use in IR (Stubbington et al. 2018a). To this end, we conceptualized and implemented a modelbased EFA adapted for IR, in which (1) environmental flows are delivered only during the abundant-riffles state and (2) baseflows are additionally delivered during prolonged dry periods to maintain the natural-predictable duration of the disconnected-pools state.

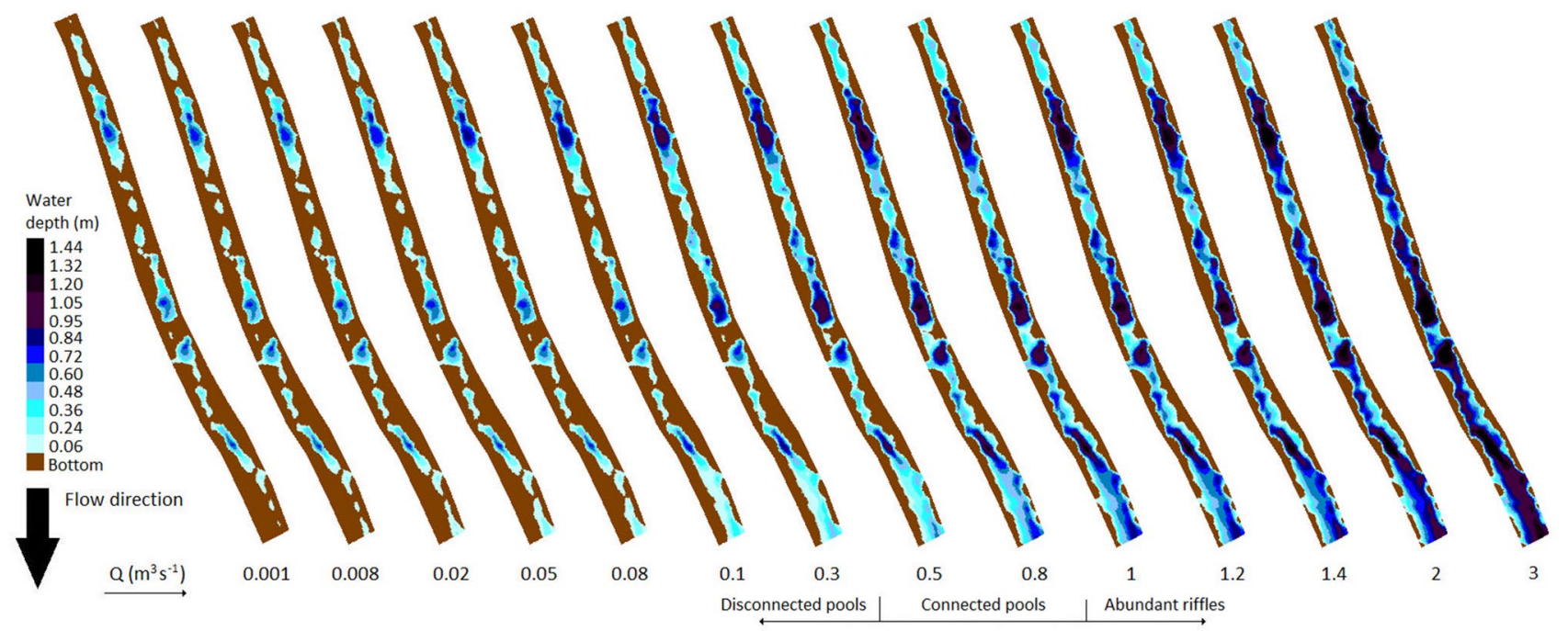

Fig. 8 Water depth simulation to facilitate the discrimination between the different aquatic states 
Regarding the first principle, BM-oriented studies have shown that Ephemeroptera, Plecoptera and Trichoptera (EPT) are gradually outnumbered by Odonata, Coleoptera and Heteroptera $(\mathrm{OCH})$ under decreasing flow permanence (Bonada et al. 2007; Sánchez-Montoya et al. 2007; Argyroudi et al. 2009; Kalogianni et al. 2017). The aforementioned shifts should not be considered negative when resulting as an adaptation to the natural IR flow variability. Unpredictably decreased flow permanence in perennial rivers may comprise a stressor for the EPT-dominated BM communities, but similarly, unpredictably prolonged flow permanence from perennially-delivered environmental flows in IR, may comprise a stressor for the OCH-dominated BM communities. This would result in a gradual replacement of the IRspecific communities by more competitive, perennial taxa, in a scheme completely inverse of that described for artificiallyintermittent perennial rivers (Côté and Darling 2010; Bogan and Lytle 2011; Belmar et al. 2013). Consequently, our first principle ensures that environmental flows of specific timing and duration will be delivered in IR to safeguard such IR-specific community transitions.

The second fundamental principle is primarily based on the responses of fish communities of IR, which, similarly to the benthic fauna, have developed morphological, physiological and life-history strategies to tolerate the high natural flow variability occurring in IR (Ferreira et al. 2007). However, although physiological-morphological adaptations have been reported for fish species in Australia, Africa and North America, fish populations in Europe lack morphological traits (resistance mechanisms) to survive drying habitats, based primarily on resilience strategies of early maturity and high fecundity (Ferreira et al. 2007) to successfully recolonize after flow resumption. In contrast, many BM taxa show increased resistance to drying by utilizing hemoglobin (Stanley et al. 1994), by developing specialized gills (Boulton 1989) or by breathing oxygen directly from the atmosphere (McDonough et al. 2011). Increased stress however will be imposed on both communities during prolonged dry periods of unpredictable duration, amplified by water abstractions. Consequently, providing low flows during artificially prolonged dry periods will likely maintain the necessary normal-predictable occurrence of pool habitats for the local fish populations to ensure survival and recovery after flow resumption.

\section{Incorporating multiple aquatic ecosystem components in the model}

Our results showed that different components of the aquatic ecosystem (benthic invertebrates and the three endemic fish species) had varying but partially overlapping habitat suitability optimums, with models predicting that the habitat preferences of all target organisms can be satisfied during the abundant-riffles state at $Q=1 \mathrm{~m}^{3} \mathrm{~s}^{-1}$. Most previous studies implementing habitat models have focused on the response of a single species to hydrological-hydraulic variation (Lamouroux et al. 2006; Daraio et al. 2010; Dunbar et al. 2012); our application highlighted, inter alia, the feasibility of implementing habitat models, which incorporate multiple ecosystem components. With the inclusion of the aquatic and riparian vegetation, the high flow-flood components (Rivaes et al. 2017) of the hydrological regime can be modelled towards more hydrologically and ecologically holistic IR EFAs.

\section{Incorporating historical hydrological information in the model}

IR-specific EFAs cannot be implemented in the absence of historical hydrological information; we showed that hydrological records of at least one-representative-year are required to estimate the timing and duration of each $\mathrm{AS}$ and, consequently, of the relevant environmental flows. This highlights the previously acknowledged importance of establishing and maintaining hydrological networks for successful hydroecological monitoring (WFD CIS 2015). However, the lack of appropriate long-term hydrological information has been an issue in hydroecological monitoring of freshwaters due to the costs of maintaining permanently operating gauging stations (Stewart 2015). In the era of climate change, hydrological networks are in decline (Stewart 2015) but as it has been previously suggested, and our study also implies, the ecological integrity of intermittent rivers cannot be ensured without, not only maintaining, but also extending the hydrological networks to include IR, providing hydrological records in the long term (Snelder et al. 2013; Beaufort et al. 2018.; Ruhi et al. 2018). The limited hydrological data available for our study reach (1.5 year-Fig. 9) may have reduced the accuracy of our estimations, but this will rather not be a problem in cases where longer hydrological records are available, thus enabling an accurate representation of the 'reality' regarding the annual AS sequence.

\section{Benthic macroinvertebrates}

The results showed that optimal habitat for benthic macroinvertebrates can be provided by a wide range of baseflows, from 0.8 to $4 \mathrm{~m}^{3} \mathrm{~s}^{-1}$ or $7 \mathrm{~m}^{3} \mathrm{~s}^{-1}$ (Figs. 6, 7). Lower discharges result in unacceptable habitat suitability based on the WFD requirements. In combination with the estimation of the timing and duration of each aquatic state (Fig. 8) the results showed that a healthy BM community can be ensured in the lowest discharge required to maintain an abundantflows state $\left(1 \mathrm{~m}^{3} \mathrm{~s}^{-1}\right)$. 
The metrics-based approach we used to assess the BM habitat requirements has been previously proposed and favored (Gore et al. 2001) but, worldwide, it has been rarely applied in relevant environmental flow assessments (Waddle and Holmquist 2011; Theodoropoulos et al. 2018c). Using this approach, and within the limitations of our BM dataset (Theodoropoulos et al. 2018a, b), the often contrasting habitat preferences of the numerous macroinvertebrate taxa can be incorporated into the model to develop overall community optimums based on BM indicators commonly applied to represent habitat quality-suitability (Englund and Malmqvist 1996; Monk et al. 2006; Waddle and Holmquist 2011). It has to be noted though that a key-taxa analysis is of equal importance in such community-based assessments to finetune the environmental flow prediction to possibly favor rare taxa of high conservation value (Armitage and Bass 2013).

\section{Fish fauna}

The results of the study showed similarities and differences in the microhabitat preferences of the selected fish fauna between the perennial and intermittent reaches at pre-dry conditions. The limnophilic Spartian minnowroach occupied deep, slow-flowing habitats (pools) in both perennial and intermittent reaches. Also limnophilic, the Evrotas minnow favored slow-flowing habitats in both perennial and intermittent reaches, with a preference for shallower habitats (glides) in intermittent reaches. The small chub retained its preference for slightly higher velocities and lower depths compared to the other two fish species, whereas for the large chub, we observed a preference shift from deep faster-flowing habitats (runs) to deep slower flowing ones (pools) in the intermittent reach.

Smaller bodied limnophilic species, i.e. the minnow and the minnowroach, and to a lesser degree the small chub, continue to exploit the increasingly available pool habitats in the intermittent reach. The more rheophilic large chub, however, actively shifted from the fastest flowing deep runs to pools, despite the availability of deep and faster flowing habitats. During river drying, refuge-seeking behavior for the large chub has been previously-documented (Vardakas et al. 2017a). Our results may also imply that adult chubs, on some unknown cue (a possible velocity change?), 'prepare' for drying by moving to pool habitats during the abundant-riffles state, before these habitats become the only ones available (obviously to avoid being stranded in a drying habitat). Studies on fish cognition, focusing on spatial learning and memory at various scales, have indicated that fish habitat selection may involve learning processes, with individual sensitivity, experience, and perception of not only current but also past environmental conditions influencing habitat selection (Braithwaite and Burt De Perera 2006; Patton and Braithwaite 2015). This is particularly important in
IR, suggesting a future focus of IR-specific EFAs on seasonally varying environmental flow scenarios. Recently, Capra et al. (2017), modeling fish microhabitat preferences in a hydropeaking river, showed that fish avoided frequently dewatered habitats, thus implying that 'environmental history' also informs habitat selection. Despite the cognitive and other adaptations of biota inhabiting highly variable environments such as IR, it is important to deliver carefully-designed, IR-adapted environmental flows during the abundant-riffles state and baseflows during prolonged dry periods, in order to maintain disconnected pools of water. Such designs may ensure the integrity of the fish communities of IR, promoting their ability to resist drying and successfully recolonize the dry habitats after flow resumption, from adjacent perennial reaches.

\section{Future challenges}

Useful outcomes were derived from the current study, and a first solid step has been made, but considering that most projects focused on IR are currently ongoing, there are yet many challenges that need to be addressed towards a widely accepted common methodology for IR-based EFAs. Issues to be considered:

1. Timing and duration of environmental flows during dry periods We favored the provision of baseflows in prolonged dry periods in order to re-establish the water pools required for fish survival. Such practice needs further research and discussion, because it changes the dry conditions to near-dry ones. The drivers for the timing and duration of such extended-dry-phase flows may be diverse and should be considered on a case-by-case basis (Acreman et al. 2014). For example, dry-phase flows could be delivered only when the duration of the dry period surpasses a certain time limit (either at the beginning or at the end). The presence of an endangered species may also be the primary driver for a differently adjusted scheme. The temperature increase above a given limit in the water pools, or the relevant decrease in the dissolved oxygen concentration may be another relevant driver.

2. Magnitude of environmental flows during dry periods It has to be noted that, HHMs alone cannot provide accurate environmental flow predictions during prolonged dry periods. The extreme, unpredictable dry periods, which may occur in IR, result in an enhancement of evapotranspiration and increased water demands for irrigation leading to groundwater depletion (Rossouw et al. 2005; McDonough et al. 2011). In this case, the baseflow calculated to maintain disconnected pools during the dry period may need an upward re-evaluation and adaptation in order to compensate for the extreme 
groundwater shortage (Ivkovic et al. 2009). Since hydrodynamic models do not account for surface-groundwater interactions, the baseflow value is predicted upon saturated hyporheic and groundwater zones. Consequently, the additional use of groundwater models is of critical importance to overcome this inefficiency and ensure accurate predictions during extreme events (Rassam et al. 2013). Surface-groundwater interaction is a major determinant of the environmental flow regime in IR and as Gardner (1999) rightfully indicates, 'the two realms can be considered as essentially one resource', which needs to be managed and protected as a whole.

3. High flow pulses, small and large floods Ideally, an environmental flow regime must include baseflows during the abundant-riffles and connected-pools states, additional baseflows during the disconnected-pools state, as well as high-flow pulses, small and large floods of specific timing and duration (O'Keeffe and Le Quesne 2009). Ecosystem-based predictions on the high flowflood components of the flow regime can be included by incorporating aquatic macrophytes and riparian vegetation, which have recently been acknowledged as ideal indicators for assessing-predicting the magnitude, timing and duration of the high-flow components of the flow regime (O'Keeffe and Le Quesne 2009; Rivaes et al. 2017). Interannually, this flow regime should be manually adapted-adjusted to include years with increased or decreased flood-magnitude based on available interannual historical hydrological records.

\section{Conclusions}

Our study showed that model-based, IR-adapted EFAs should be conceptually differentiated from their perennial alternatives. Environmental flows in IR should be specifically delivered during the abundant-riffles state to (1) ensure optimal habitat conditions and increased community resistance and (2) prevent unpredictable flow permanence, which would gradually lead to a perennial-like community composition. Additional baseflows should be delivered during prolonged dry periods to re-establish a normal-predictable disconnected-pools state, ensuring community survival and successful recovery after flow resumption. Relatively low flows can provide optimal habitat conditions during the abundant-riffles state, and extremely low flows are capable of maintaining disconnected pools during dry periods. However, during prolonged dry periods, increased baseflows should be delivered to compensate for the extreme groundwater depletion and increased evapotranspiration. Historical hydrological information should be additionally used for the determination of the timing and duration of each aquatic state, to facilitate the development of an annually-repeating environmental flow regime. In conclusion, IR-adapted EFAs should provide the optimal habitat conditions necessary to ensure increased community resistance and successful recovery rates in an often extreme, but naturally variable aquatic environment.

Acknowledgements The authors wish to thank Maria Stoumboudi, Petros Kouraklis, Sofia Giakoumi, Dimitris Kommatas and Aikaterini Vourka for their participation in the ichthyological field work. This study was conducted within the frame of the European Communities 7th Framework Programme under Grant Agreement no 603629-ENV-2013-6.2.1-GLOBAQUA.

Open Access This article is distributed under the terms of the Creative Commons Attribution 4.0 International License (http://creativeco mmons.org/licenses/by/4.0/), which permits unrestricted use, distribution, and reproduction in any medium, provided you give appropriate credit to the original author(s) and the source, provide a link to the Creative Commons license, and indicate if changes were made.

\section{References}

Acreman MC, Dunbar MJ (2004) Defining environmental river flow requirements: a review. Hydrol Earth Syst Sci 8:861-876

Acreman M, Arthington AH, Colloff MJ, Couch C, Crossman ND, Dyer F, Overton I, Pollino CA, Stewardson MJ, Young W (2014) Environmental flows for natural, hybrid, and novel riverine ecosystems in a changing world. Front Ecol Environ 12:466-473

Ahmadi-Nedushan B, St-Hilaire A, Bérubé M, Robichaud E, Thiémonge N, Bobée B (2006) A review on statistical methods for the evaluation of the aquatic habitat suitability for instream flow assessment. River Res Appl 22:503-523

Argyroudi A, Chatzinikolaou Y, Poirazidis K, Lazaridou M (2009) Do intermittent and ephemeral Mediterranean rivers belong to the same river type? Aquat Ecol 43:465-476

Armitage PD, Bass JAB (2013) Long-term resilience and short-term vulnerability of South Winterbourne macroinvertebrates. Proc Dorset Nat Hist Archaeol Soc 134:41-55

Austin M (2007) Species distribution models and ecological theory: a critical assessment and some possible new approaches. Ecol Model 200:1-19

Beaufort A, Lamouroux N, Pella H, Datry T, Sauquet E (2018) Extrapolating regional probability of drying of headwater streams using discrete observations and gauging networks. Hydrol Earth Syst Sci 22:3033-3051

Bêche LA, Connors PG, Resh VH, Merenlender AM (2009) Resilience of fishes and invertebrates to prolonged drought in two California streams. Ecography 32:778-788

Belmar O, Velasco J, Gutiérrez-Cánovas C, Mellado-Díaz A, Millán A, Wood PJ (2013) The influence of natural flow regimes on macroinvertebrate assemblages in a semiarid Mediterranean basin. Ecohydrology 6:363-379

Bernardo JM, Alves MH (1999) New perspectives for ecological flow determination in semi-arid regions: a preliminary approach. River Res Appl 15:221-229

Bogan MT, Lytle DA (2011) Severe drought drives novel community trajectories in desert stream pools. Freshw Biol 56:2070-2081

Bogan MT, Boersma KS, Lytle DA (2015) Resistance and resilience of invertebrate communities to seasonal and supraseasonal drought in arid-land headwater streams. Freshw Biol 60:2547-2558 
Bogan MT, Chester ET, Datry T, Murphy AL, Robson BJ, Ruhi A, Stubbington R, Whitney JE (2017) Resistance, resilience and community recovery in intermittent rivers and ephemeral streams. In: Datry T, Bonada N, Boulton AJ (eds) Intermittent rivers and ephemeral streams: ecology and management. Academic Press, London, pp 349-376

Bonada N, Rieradevall M, Prat N (2007) Macroinvertebrate community structure and biological traits related to flow permanence in a Mediterranean river network. Hydrobiologia 589:91-106

Boulton AJ (1989) Over-summering refuges of aquatic macroinvertebrates in two intermittent streams in central Victoria. Trans R Soc S Aust 113:23-34

Bovee KD (1982) A guide to stream habitat analysis using the instream flow incremental methodology. Instream flow information paper 12/248. US Fish and Wildlife Service, Cooperative Instream Flow Group

Bovee KD (1986) Development and evaluation of habitat suitability criteria for use in the instream flow incremental methodology. Instream flow information paper \#21 FWS/OBS-86/7. USDI Fish and Wildlife Service, Washington DC

Bovee KD, Lamb BL, Bartholow JM, Stalnaker CB, Taylor J, Henriksen J (1998) Stream habitat analysis using the instream flow incremental methodology. US Geological Survey, Biological Resources Division Information and Technology, Fort Collins

Braithwaite VA, Burt De Perera T (2006) Short-range orientation in fish: how fish map space. Mar Freshw Behav Phy 39:37-47

Brisbane Declaration (2007) The Brisbane declaration: environmental flows are essential for freshwater ecosystem health and human well-being. In: 10th international river symposium, 3-6 September 2007, Brisbane, Australia

Brookes CJ, Kumar V, Lane SN (2010) A comparison of fuzzy, Bayesian and weighted average formulations of an in-stream habitat suitability model. In: Proceedings of the international congress on environmental modelling and software, 5-8 Jul 2010, Ottawa, Canada

Brosse S, Lek S (2000) Modelling roach (Rutilus rutilus) microhabitat using linear and nonlinear techniques. Freshw Biol 44:441-452

Canadian Hydraulics Centre (CHC) (2011) Blue Kenue reference manual. Canadian Hydraulics Centre, National Research Council, Ottawa

Capra H, Plichard L, Bergé J, Pella H, Ovidio M, McNeil E, Lamouroux N (2017) Fish habitat selection in a large hydropeaking river: strong individual and temporal variations revealed by telemetry. Sci Total Environ 578:109-120

Cazemier MM, Querner EP, van Lanen HAJ, Gallart F, Prat N, Tzoraki O, Froebrich J (2011) Hydrological analysis of the Evrotas basin, Greece. Low flow characterization and scenario analysis. Alterra Report 2249, Wageningen

Chakona A, Phiri C, Magadza CHD, Brendonck L (2008) The influence of habitat structure and flow permanence on macroinvertebrate assemblages in temporary rivers in northwestern Zimbabwe. Hydrobiologia 607:199-209

Cid N, Bonada N, Carlson SM, Grantham TE, Gasith A, Resh VH (2017) High variability is a defining component of mediterraneanclimate rivers and their biota. Water 9:52

Conallin J, Wilson E, Campbell J (2018) Implementation of environmental flows for intermittent river systems: adaptive management and stakeholder participation facilitate implementation. Environ Manag 61:497-505

Copp GH (1989) Electrofishing for fish larvae and $0+$ juveniles: equipment modifications for increased efficiency with short fishes. Aquac Fish Manag 20:177-186

Costigan K, Kennard MJ, Leigh C, Sauquet E, Datry T, Boulton AJ (2017) Flow regimes in intermittent rivers and ephemeral streams.
In: Datry $\mathrm{T}$, Bonada $\mathrm{N}$, Boulton $\mathrm{AJ}$ (eds) Intermittent rivers and ephemeral streams: ecology and management. Academic Press, London, pp 51-78

Côté IM, Darling ES (2010) Rethinking ecosystem resilience in the face of climate change. PLoS Biol 8(7):e1000438

Daraio JA, Weber LJ, Newton TJ (2010) Hydrodynamic modeling of juvenile mussel dispersal in a large river: the potential effects of bed shear stress and other parameters. J N Am Benthol Soc $29: 838-851$

Datry T, Larned ST, Scarsbrook M (2007) Responses of hyporheic invertebrate assemblages to large-scale variation in flow permanence and surface-subsurface exchange. Freshw Biol 52:1452-1462

Datry T, Larned ST, Tockner K (2014) Intermittent rivers: a challenge for freshwater ecology. Bioscience 64:229-235

Datry T, Singer G, Sauquet E, Jorda-Capdevila D, Von Schiller D, Subbington R, Magand C, Pařil P, Miliša M, Acuña V, Alves M, Augeard B, Brunke M, Cid N, Csabai Z, England J, Froebrich J, Koundouri P, Lamouroux N, Martí E, Morais M, Munné A, Mutz M, Pesic V, Previšić A, Reynaud A, Robinson C, Sadler J, Skoulikidis N, Terrier B, Tockner K, Vesely D, Zoppini A (2017) Science and management of intermittent rivers and ephemeral streams (SMIRES). Res Ideas Outcomes 3:e21774

Dunbar MJ, Alfredsen K, Harby A (2012) Hydraulic-habitat modelling for setting river flow needs for salmonids. Fish Manag Ecol 19:500-517

Englund G, Malmqvist B (1996) Effects of flow regulation, habitat area and isolation on the macroinvertebrate fauna of rapids in North Swedish Rivers. Regul River 12:433-445

European Union Council (2000) Directive 2000/60/EC of the European Parliament and of the Council of 23 October 2000 establishing a framework for Community action in the field of water policy. Off J Eur Community L327:1-72

Ferreira T, Olivera J, Caiola N, De Sostoa A, Casals F, Cortes R, Economou A, Zogaris S, Garcia-Jalon D, Ilhéu M, MartinezCapel F, Pont D, Rogers C, Prenda J (2007) Ecological traits of fish assemblages from mediterranean Europe and their responses to human disturbance. Fish Manag Ecol 14:473-481

Fritz KM, Dodds WK (2004) Resistance and resilience of macroinvertebrate assemblages to drying and flood in a tallgrass prairie stream system. Hydrobiologia 527:99-112

Fukuda S, Mouton AM, De Baets B (2011) Abundance versus presence/absence data for modelling fish habitat preference with a genetic Takagi-Sugeno fuzzy system. Environ Monit Assess 184:6159-6171

Galland JC, Gontal N, Hervouet JM (1991) TELEMAC: a new numerical model for solving shallow water equations. Adv Water Resour 14:138-148

Gallart F, Prat N, García-Roger EM, Latron J, Rieradevall M, Llorens P, Barberá GG, Brito D, De Girolamo AM, Lo Porto A, Neves R, Nikolaidis NP, Perrin JL, Querner EP, Quiñonero JM, Tournoud MG, Tzoraki O, Froebrich J (2012) A novel approach to analysing the regimes of temporary streams in relation to their controls on the composition and structure of aquatic biota. Hydrol Earth Syst Sc 16:3165-3182

Gardner KM (1999) The importance of surface water/groundwater interaction. EPA Report: EPA-910-R-99-013. Environmental Protection Agency, Washington, DC

Gillenwater D, Granata T, Zika U (2006) GIS-based modeling of spawning habitat suitability for walleye in the Sandusky River, Ohio, and implications for dam removal and river restoration. Ecol Eng 28:311-323

Gopal B (2013) Methodologies for the assessment of environmental flows. In: Gopal B (ed) Environmental flows: an introduction for 
water resources managers. National Institute of Ecology, New Delhi, pp 129-182

Gore JA, Layzer JB, Mead J (2001) Macroinvertebrate instream flow studies after 20 years: a role in stream management and restoration. Regul River 17:527-542

Hervouet JM (2007) Hydrodynamics of free surface flows: modelling with the finite element method. Wiley, West Sussex

IUCN (2017) The IUCN red list of threatened species. Version 2017-3. http://www.iucnredlist.org. Accessed 8 Jun 2018

Ivkovic KM, Letcher RA, Croke BFW (2009) Use of a simple surfacegroundwater interaction model to inform water management. Aust J Earth Sci 56:71-80

Kalogianni E, Vourka A, Karaouzas I, Vardakas L, Laschou S, Skoulikidis ThN (2017) Combined effects of water stress and pollution on macroinvertebrate and fish assemblages in a Mediterranean intermittent river. Sci Total Environ 603-604:639-650

Kottelat M, Barbieri R (2004) Pseudophoxinus laconicus, a new species of minnow from Peloponnese, Greece, with comments on the West Balkan Pseudophoxinus species (Teleostei: Cyrpinidae). Ichthyol Explor Freshw 15:147-160

Lamouroux N, Olivier JM, Capra H, Zylberblat M, Chandesris A, Roger P (2006) Fish community changes after minimum flow increase: testing quantitative predictions in the Rhône River at Pierre-Bénite, France. Freshw Biol 51:1730-1743

Lamouroux N, Mérigoux S, Capra H, Dolédec S, Jowett IG, Statzner B (2010) The generality of abundance-environment relationships in microhabitats: a comment on Lancaster and Downes. River Res Appl 26:915-920

Larned S, Datry T, Arscott D, Tockner K (2010) Emerging concepts in temporary-river ecology. Freshw Biol 55:717-738

Leitner P, Hauer C, Graf W (2017) Habitat use and tolerance levels of macroinvertebrates concerning hydraulic stress in hydropeaking rivers-a case study at the Ziller River in Austria. Sci Total Environ 575:112-118

Lytle DA, Poff NL (2004) Adaptation to natural flow regimes. Trends Ecol Evol 19:94-100

McDonough OT, Hosen JD, Palmer MA (2011) Temporary streams: The hydrology, geography, and ecology of non-perennially flowing waters. In: Elliot HS, Martin LE (eds) River ecosystems: dynamics, management and conservation. Nova Science Publishers, New York

Monk WA, Wood PJ, Hannah DM, Wilson DA, Extence CA, Chadd RP (2006) Flow variability and macroinvertebrate community response within riverine systems. River Res Appl 22:595-615

O'Keeffe J, Le Quesne T (2009) Keeping rivers alive. A primer on environmental flows and their assessment. WWF Water Security Series 2, WWF. http://assets.wwf.org.uk/downloads/keepi ng_rivers_alive.pdf. Accessed 6 Sept 2018

Papadaki C, Soulis K, Ntoanidis L, Zogaris S, Dercas N, Dimitriou E (2017) Comparative assessment of environmental flow estimation methods in a Mediterranean mountain river. Environ Manag 60:280-292

Patton BW, Braithwaite VA (2015) Changing tides: ecological and historical perspectives on fish cognition. WIREs Cogn Sci 6:159-176

Prat N, Gallart F, Von Schiller D, Polesello S, García-Roger EM, Latron J, Rieradevall M, Llorens P, Barberá GG, Brito D, De Girolamo AM, Dieter D, Lo Porto A, Buffagni A, Erba S, Nikolaidis NP, Querner EP, Tournoud MG, Tzoraki O, Skoulikidis N, Gomez R, Sanchez-Montoya MM, Tockner K, Froebrich J (2014) The Mirage Toolbox: an integrated assessment tool for temporary streams. River Res Appl 30:1318-1334

R Core Team (2014) R: A language and environment for statistical computing. R Foundation for Statistical Computing, Vienna, Austria. http://www.R-project.org/. Accessed 5 Sept 2018

Rassam DW, Peeters L, Pickett T, Jolly I, Holz L (2013) Accounting for surface-groundwater interactions and their uncertainty in river and groundwater models: a case study in the Namoi River, Australia. Environ Model Softw 50:108-119

Rivaes R, Boavida I, Santos JM, Pinheiro AN, Ferreira T (2017) Importance of considering riparian vegetation requirements for the longterm efficiency of environmental flows in aquatic microhabitats. Hydrol Earth Syst Sci 21:5763-5780

Rossouw L, Avenant MF, Seaman MT, King JM, Barker CH, Du Preez PJ, Pelser AJ, Roos JC, Van Staden JJ, Van Tonder GJ, Watson M (2005) Environmental water require ments in non-perennial systems. WRC Report No. 1414/1/05. Water Research Commission, Pretoria

Ruhi A, Messager ML, Olden JD (2018) Tracking the pulse of Earth's fresh waters. Nat Sustain 1:198-203

Sánchez-Montoya MD, Puntí T, Suárez ML, Vidal-Abarca MD, Rieradevall M, Poquet JM, Zamora-Muñoz C, Robles S, Álvarez M, Alba-Tercedor J, Toro M, Pujante AM, Munné A, Prat N (2007) Concordance between ecotypes and macroinvertebrate assemblages in Mediterranean streams. Freshw Biol 52:2240-2255

Santos JM, Ferreira MT (2008) Microhabitat use by endangered Iberian cyprinids nase Iberochondrostoma almacai and chub Squalius aradensis. Aquat Sci 70:272-281

Schneider M, Noack M, Gebler T, Kopecki I (2010) Handbook for the Habitat Simulation Model CASiMiR, Module CASiMiR, Base Version. http://www.casimir-software.de/ENG/download_eng. html. Accessed 8 Jun 2018

Schneider A, Jost A, Coulon C, Silvestre M, Théry S, Ducharne A (2017) Global-scale river network extraction based on high resolution topography and constrained by lithology, climate, slope, and observed drainage density. Geophys Res Lett 44:2773-2781

Skoulikidis NT, Vardakas L, Karaouzas I, Economou AN, Dimitriou E, Zogaris S (2011) Assessing water stress in Mediterranean lotic systems: insights from an artificially intermittent river in Greece. Aquat Sci 73:581-597

Skoulikidis NT, Vardakas L, Amaxidis Y, Michalopoulos P (2017a) Biogeochemical processes controlling aquatic quality during drying and rewetting events in a Mediterranean non-perennial river reach. Sci Total Environ 575:378-389

Skoulikidis N, Sabater S, Datry T, Morais M, Buffagni A, Dörflinger G, Zogaris S, Sánchez-Montoya MM, Bonada N, Kalogianni E, Rosado J, Vardakas L, De Girolamo AM, Tockner K (2017b) Non-perennial Mediterranean rivers in Europe: status, pressures, and challenges for research and management. Sci Total Environ 577:1-18

Snelder TH, Datry T, Lamouroux N, Larned ST, Sauquet E, Pella H, Catalogne C (2013) Regionalization of patterns of flow intermittence from gauging station records. Hydrol Earth Syst Sc 17:2685-2699

Stanley EH, Buschman DL, Boulton AJ, Grimm NB, Fisher SG (1994) Invertebrate resistance and resilience to intermittency in a desert stream. Am Midl Nat 131:288-300

Stewart B (2015) Measuring what we manage-the importance of hydrological data to water resources management. In: Cudennec C, Demuth S, Mishra A, Young G (eds) Hydrological sciences and water security: past, present and future. PIAHS vol 366, pp 80-85

Stubbington R, England J, Wood PJ, Sefton CEM (2017) Temporary streams in temperate zones: recognizing, monitoring and restoring transitional aquatic-terrestrial ecosystems. WIREs Water 4:c1223

Stubbington R, Chadd R, Cid N, Zoltán C, Miliša M, Morais M, Munné A, Pařil P, Pešić V, Tziortzis I, Verdonschot RCM, Datry $\mathrm{T}$ (2018a) Biomonitoring of intermittent rivers and ephemeral streams in Europe: current practice and priorities to enhance ecological status assessments. Sci Total Environ 618:1096-1113

Stubbington R, England J, Acreman M, Wood PJ, Westwood C, Boon P, Mainstone C, Macadam C, Bates A, House A, Jorda-Capdevila D (2018b) The natural capital of temporary rivers: characterising 
the value of dynamic aquatic-terrestrial habitats. Valuing nature natural capital synthesis report VNP12, UK

Tharme RE (2003) A global perspective on environmental flow assessment: emerging trends in the development and application of environmental flow methodologies for rivers. River Res Appl 19:397-441

Theodoropoulos C, Skoulikidis N, Stamou A (2016) Habfuzz: a tool to calculate the instream hydraulic habitat suitability using fuzzy logic and fuzzy Bayesian inference. J Open Sour Softw 1(6):82. https://doi.org/10.21105/joss.00082

Theodoropoulos C, Vourka A, Skoulikidis N, Rutschmann P, Stamou A (2018a) Evaluating the performance of habitat models for predicting the environmental flow requirements of benthic macroinvertebrates. J Ecohydraulics. https://doi.org/10.1080/24705 357.2018.1440360

Theodoropoulos C, Skoulikidis N, Stamou A, Dimitriou E (2018b) Spatiotemporal variation in benthic-invertebrates-based physical habitat modelling: can we use generic instead of local and seasonspecific habitat suitability criteria? Water 10:1508

Theodoropoulos C, Skoulikidis N, Rutschmann P, Stamou A (2018c) Ecosystem-based environmental flow assessment in a Greek regulated river with the use of 2D hydrodynamic habitat modelling. River Res Appl 34:538-547

Vardakas L, Kalogianni E, Zogaris S, Koutsikos N, Vavalidis T, Koutsoubas D, Skoulikidis N (2015) Distribution patterns of fish assemblages in an Eastern Mediterranean intermittent river. Knowl Manag Aquat Ecosyst 416:30

Vardakas L, Kalogianni E, Economou AN, Koutsikos N, Skoulikidis NT (2017a) Mass mortalities and population recovery of an endemic fish assemblage in an intermittent river reach during drying and rewetting. Fund Appl Limnol 190:331-347

Vardakas L, Kalogianni E, Papadaki C, Vavalidis T, Mentzafou A, Koutsoubas D, Skoulikidis NT (2017b) Defining critical habitat conditions for the conservation of three endemic and endangered cyprinids in a Mediterranean intermittent river prior to the onset of drought. Aquat Conserv 27:1270-1280

Waddle TJ, Holmquist JG (2011) Macroinvertebrate response to flow changes in a subalpine stream: predictions from two-dimensional hydrodynamic models. River Res Appl 29:366-379

WFD CIS Guidance Document No. 31 (2015) Ecological flows in the implementation of the Water Framework Directive (Technical Report-2015-086). Directorate General Environment of the European Commission, Brussels

Whiterod NS, Hammer M, Vilizzi L (2017) Linking the recruitment and survivorship of a freshwater stream-specialist fish species to flow metrics in Mediterranean climate temporary streams. Hydrol Sci J 62:1630-2614 